\title{
Selective dry cow therapy effect on milk yield and somatic cell count: A retrospective cohort study
}

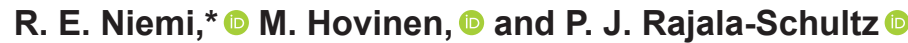 \\ Department of Production Animal Medicine, Faculty of Veterinary Medicine, University of Helsinki, Paroninkuja 20, 04920 Saarentaus, Finland
}

\begin{abstract}
Antibiotic dry cow therapy (aDCT) at the end of lactation is an effective mastitis control measure. Selective dry cow therapy means that only infected or presumedinfected cows are treated, instead of aDCT being used as a treatment for all cows. Because antibiotic resistance poses a global threat, livestock production is under increasing pressure to reduce antibiotic use. Changes in management should not, however, impair animal welfare or cause significant economic losses. Our objective was to compare milk yield and somatic cell count (SCC) between aDCT-treated and untreated cows in herds that used selective aDCT, taking into account risk factors for reduced yield and high SCC. The information source was 2015 to 2017 Dairy Herd Improvement data, with 4,720 multiparous cows from 172 Finnish dairy farms. The response variables were testday milk yield $(\mathrm{kg} / \mathrm{d})$ and naturally log-transformed composite SCC $(\times 1,000$ cells $/ \mathrm{mL})$ during the first $154 \mathrm{~d}$ in milk (DIM). The statistical tool was a linear mixed-effects model with 2-level random intercepts, cows nested within herds, and a first-order autoregressive $[\mathrm{AR}(1)]$ correlation structure. The overall proportion of aDCT-treated cows was 25\% $(1,176 / 4,720)$. Due to the interaction effect, SCC on the last test day prior to dry-off affected postcalving milk yield differently in aDCT-treated cows than in untreated cows. A higher SCC prior to dry-off correlated with a greater daily yield difference after calving between cows treated and untreated. The majority of cows had SCC $<200,000$ cells/mL before dry-off, and as SCC before dry-off decreased, difference in yield between aDCT-treated and untreated cows decreased. Postcalving SCC was lower for aDCT-treated cows compared with untreated cows. To illustrate, for cows with an SCC of 200,000 cells/mL before dry-off, compared with untreated cows, aDCTtreated cows produced $0.97 \mathrm{~kg} / \mathrm{d}$ more milk and, at 45 DIM, had an SCC that was 20,000 cells/mL lower.
\end{abstract}

Received June 24, 2021.

Accepted November 3, 2021.

*Corresponding author: riitta.e.niemi@helsinki.fi
Higher late-lactation SCC and lactational mastitis treatments were associated with higher postcalving SCC. A dry period lasting more than $30 \mathrm{~d}$ was associated with higher yields but not with SCC. Our findings indicate that a missed aDCT treatment for a high-SCC cow has a negative effect on subsequent lactation milk yield and SCC, which emphasizes the importance of accurate selection of cows to be treated.

Key words: drying off, milk production, composite somatic cell count, time series analysis

\section{INTRODUCTION}

Mastitis is the most common disease in dairy cows, causing significant economic effects on milk production and compromising animal welfare (Rajala-Schultz et al., 1999; Halasa et al., 2007). Antibiotic dry cow therapy (aDCT) is an effective way to control mastitis, as cows are susceptible to new IMI at the time of drying-off and again during the periparturient period (Dingwell et al., 2003; Bradley and Green, 2004). Several countries use a blanket DCT approach, in which intramammary antibiotics are infused at dry-off into all quarters of all cows (Bertulat et al., 2015; USDA, 2016; Fujiwara et al., 2018). This treatment recommendation is based on the 5-point plan created in the 1960s and has since been a tool to reduce mastitis (Neave et al., 1969). Antibiotic resistance became apparent in the same decade (Anonymous, 1966) and is now a serious global health threat, according to the World Health Organization, among others (World Health Organization, 2015; OIE, 2016; EMA and EFSA, 2017). In addition to the health threat, consumption of antibiotics considerably affects ecology and the environment (Larsson et al., 2007). Because the most essential methods for controlling antibiotic resistance are by restricting the use of antibiotics and improving hygiene, optimizing all antibiotic therapy use is crucial (McEwen and Collignon, 2018).

In the selective DCT approach, only infected or presumed-infected cows receive treatment, and this has always been the prevailing treatment practice in the Nordic countries (Rajala-Schultz et al., 2021). The Nordic guidelines additionally advise farmers to identify causal 
mastitis pathogens by frequent bacteriological analysis and to assess treatment prognosis (Nordic Guidelines for Mastitis Therapy, 2009). The selective treatment practice later expanded outside the Nordic countries. In 2012, the Netherlands banned prophylactic use of antibiotics in livestock, and, as a result, Dutch dairy farmers switched to the selective DCT approach (Vanhoudt et al., 2018; Krattley-Roodenburg et al., 2021).

Recent results suggest that selective DCT succeeds without compromising udder health even if implemented only for infected quarters (Kabera et al., 2020). Moreover, an alternative means to avoid antibiotic treatment is by administering intramammary teat sealants (ITS) to healthy quarters (Rabiee and Lean, 2013; Winder et al., 2019a). In high-yielding cows, the formation of a protective keratin plug may be delayed or deficient, and the ITS effectively mimics this natural defense mechanism (Dingwell et al., 2004).

Livestock production is facing increasing consumer and regulatory pressures against antibiotic use, but at the same time, changes in management should not impair animal welfare or cause the farmer economic losses. Therefore, research must provide a comprehensive understanding of aDCT and other mastitis control strategies. Although several experimental studies compare selective DCT with blanket DCT, results are in part controversial, with notable between-study variation (Scherpenzeel et al., 2014; Winder et al., 2019b; Rowe et al., 2020b). Recent economic analyses suggest that selective DCT is profitable compared with blanket DCT, particularly on farms with good udder health (Scherpenzeel et al., 2018; Rowe et al., 2021). However, because udder health and milk production vary between herds, optimal herd-specific treatment proportions and sufficient selection methods are likely to vary (Scherpenzeel et al., 2018; Niemi et al., 2020). As selective DCT is not yet standard practice in many countries, only a few observational studies concern the effects of selective DCT on commercial dairy cow milk yield and udder health (Vanhoudt et al., 2018; Niemi et al., 2020, 2021). Proper understanding of the advantages and disadvantages of selective DCT requires observational research data from herds that use selective DCT as their standard practice alongside data from experimental field trials.

Cow composite SCC is a readily available measurement to evaluate udder health. A healthy udder has an SCC $<100,000$, and with an SCC $\geq 200,000$, a cow is likely to have IMI in one or more quarters (Dohoo and Leslie, 1991; Sordillo et al., 1997). Sensitivity and specificity of IMI detection vary according to the pathogen involved, the number of infected quarters, the time of milk sampling, and the method of bacteriological exam- ination. Major pathogens more frequently elicit higher SCC than minor pathogens (Barkema et al., 1999).

Our objective was to compare milk yield and SCC during the first half of lactation between selectively aDCT-treated and untreated cows, taking into account risk factors for reduced milk yield and high SCC.

\section{MATERIALS AND METHODS}

\section{DHI Data}

Preliminary retrospective data included DHI records for 22,270 cows registered on 241 conventional dairy farms from 2015 to 2017. The data source was the Finnish Milk Recording database (MTech Digital Solutions, Vantaa, Finland). These farmers responded to a questionnaire between January and May 2017. The questionnaire was addressed to dairy farmers who were part of the Finnish DHI recording system in 2016. During that year, the recording system included approximately $70 \%$ of Finnish herds and $80 \%$ of Finnish cows. Of approximately 5,400 farms, responding farms numbered 715, and farms that granted permission to use their DHI data for research, 241. Vilar et al. (2018) described the questionnaire results. Niemi et al. (2020, 2021) reported detailed results based on herd- and cowlevel DHI data from all 241 farms. Of these 241 farms, the current study used a subset of the DHI data consisting of only the farms whose standard practice was the selective DCT approach. The number of farms totaled 192, and the number of multiparous cows, 5,550 .

The DHI data comprised cow-level information on test-day SCC and milk yield, 305-d milk yield, 305-d ECM, DIM on a test day, breed, parity, calving dates, dry-off dates, and recording of treatments for mastitis during lactation and at dry-off. Data also included culling dates and reasons for culling. Finnish Ayrshires and Holsteins accounted for approximately $98 \%$ of the national dairy cow population during the investigation period, and our data included only these 2 breeds. The usual test-day interval for milk production measurements was $1 \mathrm{mo}$ and for SCC measurements either 1 or 2 mo. For a minor proportion of cows, test-day measurements were available at 2 -wk intervals. The first test-day SCC for all cows was within 5 to $45 \mathrm{~d}$ after calving, to ensure that the first SCC measurement was neither too close to nor too far from calving (Niemi et al., 2021). Dry-off dates were between autumn 2015 and the end of 2017. The dry period length was within 30 to $90 \mathrm{~d}$ (Niemi et al., 2021).

Lactational mastitis treatments for individual cows in the health-recording database are classified for clinical or subclinical mastitis. As these records lack 
information on symptoms or symptom severity, all mastitis treatments administered during lactation were uniformly defined for data analysis simply as mastitis treatment. A unique cow-level record code distinguishes aDCT from other treatments. To obtain a herd-level descriptive result from these cow-level aDCT treatments, we calculated the herd-specific aDCT percentage, which was the number of aDCT-treated cows divided by the number of that herd's multiparous cows. Antibiotics are accessible for Finnish farms only with a veterinary prescription. Consequently, farmers initiate antibiotic treatments under the advice or supervision of a veterinarian.

\section{Selective DCT Approach}

Information about the herd-level selective DCT approach and the duration of the approach was based on our questionnaire data (Vilar et al., 2018; Niemi et al., 2020, 2021). Additionally, these data included the approximate proportion of aDCT-treated cows per herd. The 4 categories were (1) a few cows, (2) one-quarter of the cows, (3) half the cows, and (4) over half of the cows. To compare the questionnaire data with the percentage of aDCT-treated cows based on the DHI data, we converted the categories to the following numerical values: (1) $12.5 \%$, (2) $25 \%$, (3) $50 \%$, and (4) $75 \%$. During the study period, the 3 antibiotic dry cow products on the Finnish market contained benzylpenicillin 400,000 IU and framycetin $100 \mathrm{mg}$ (Umpimycin Vet, Boehringer Ingelheim Vetmedica $\mathrm{GmbH}$ ), cloxacillin $500 \mathrm{mg}$ (Orbenin Retard Vet, Zoetis Finland Oy), and ampicillin $250 \mathrm{mg}$ and cloxacillin $500 \mathrm{mg}$ (Kloxerate Retard, Norbrook Laboratories Limited).

\section{Exclusion Criteria}

The 205 cows lacking a dry-off date and the 3 cows lacking a 305-d milk yield were excluded from the data, because that information was considered necessary for the data analysis. Practically all Finnish farms use a gradual milk cessation method (Vilar et al., 2018). The dry-off date in the DHI data is either the start date of milk cessation or the date of last milking. To reduce any potential misclassification bias, the exclusion criterion was to reject those aDCT-treated cows with more than a 14-d difference between dry-off date and aDCT treatment date (91 cows). The herd-level proportion of aDCT-treated cows was compared with the corresponding approximated proportion of aDCT-treated cows based on the questionnaire. We excluded farms with $\geq 40 \%$ fewer treatment records than expected based on the questionnaire (20 farms, 484 cows), considering it possible that deficiencies existed in the record-keeping of aDCT treatments on these farms. This difference was an absolute difference between the proportion of DHIbased treatments and the proportion of survey-based treatments. To ensure that the last SCC measurement was not too far in time from dry-off, we excluded cows without a test-day SCC within 90 d before a dry-off date (47 cows). After exclusions, farms totaled 172, and cows totaled 4,720.

\section{Statistical Analysis}

The response variables of 2 statistical models were cow-level milk yield $(\mathrm{kg} / \mathrm{d})$ and naturally log-transformed composite SCC $\times 1,000$ cells $/ \mathrm{mL}(\operatorname{lnSCC})$, which were repeatedly measured on test days during the first 154 DIM. These test-day measurements were spaced into equal 14-d periods, which resulted in 11 periods. Statistical analysis included only the most recent calving of each cow. Data exploration followed the protocol described in Zuur et al. (2010). Due to the lack of independence between repeated measurements within cows and between cows within the same herd, we used a Gaussian linear mixed-effects model with 2-way nested random intercepts and a first-order autoregressive correlation structure $[\mathbf{A R}(\mathbf{1})]$. The 2-way specification for the random intercepts was cows nested within herds. The AR(1) structure showed the desired decay in correlation with increasing distance across time. The time covariate specification of the $\mathrm{AR}(1)$ structure was the equidistant time periods. The likelihood ratio test indicated that the AR(1) structure significantly improved the fit of the model $(P<0.0001)$ compared with the 2-level random intercepts model without it.

Table 1 lists the covariates evaluated in the models. The main covariate of interest was cow-level aDCT at dry-off. The lactation curve was modeled with combined exponential and linear function, as in the equation by Wilmink (1987; Table 1). The constant $\mathrm{k}$ of the function relates to the time of peak lactation and was set at 0.05. Based on data exploration, apparent collinearity existed between parity and 305-d milk yield, and only 305-d milk yield was included in the models. The preceding-lactation milk yield was considered a prerequisite for predicting postpartum lactation, and, in addition, farmers may be more likely to administer aDCT to their high-yielding cows. Based on biological knowledge and data exploration, the effect of increasing SCC or milk yield near dry-off may have a different effect in aDCT-treated cows than in untreated cows. Therefore, in the models, we evaluated the 2-way interaction between aDCT and $\operatorname{lnSCC} 0$ to $90 \mathrm{~d}$ before dry-off and the 2-way interaction between aDCT and milk yield 0 to $90 \mathrm{~d}$ before dry-off. Mean $\operatorname{lnSCC}$ during 154 DIM was included in the model when the response 
Table 1. Specification of the fixed effects evaluated in the linear mixed models

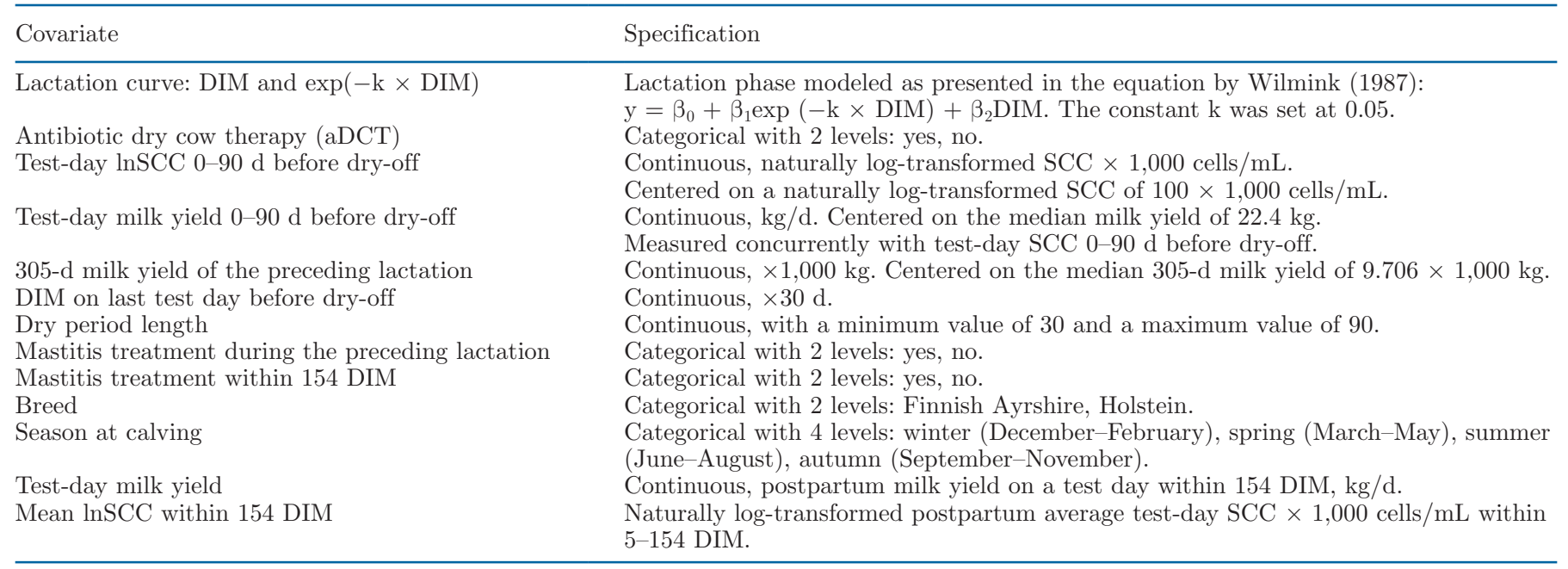

variable was daily milk yield. Correspondingly, when lnSCC was the response variable, the model comprised test-day milk yield as a covariate.

Model comparison was based on maximum likelihood estimation. The model selection tool was the Akaike information criterion (AIC), and the selected model was the model with the lowest AIC. In the final models for both outcomes, parameter estimation was based on restricted maximum likelihood. Model assumptions were verified by residual plotting. As a goodness-offit measure, marginal and conditional $\mathrm{R}^{2}$ coefficients were calculated for the final models (Nakagawa and Schielzeth, 2013). To verify that the models complied with observations, 1,000 data sets were randomly simulated from the final models. The density curves of the simulated data sets were compared with the respective density curves of the observed milk yield and $\operatorname{lnSCC}$, which illustrated the fact that the simulated data did not markedly deviate from the observations (Zuur and Ieno, 2016). Statistical analyses were performed with $\mathrm{R}$ version 4.0 .3 (https://www.r-project.org/) using $\mathrm{R}$ Studio Version 1.4.1106 (http://www.rstudio.com) with the package nlme (Pinheiro et al., 2021). The packages ggplot2 (Wickham, 2016) and lattice (Sarkar, 2008) served to produce graphs. The package MuMIn (Barton, 2020) was used to calculate the marginal and conditional $\mathrm{R}^{2}$ coefficients.

\section{RESULTS}

\section{Descriptive Results}

Our sample appeared to be representative of Finnish farms, although the herd size was slightly larger, milk production higher, and SCC lower than on average Finnish dairy farms during that period (Table 2). Of the cows we studied, the proportion originating from a farm with a parlor or automatic milking system was $72 \%(3,413 / 4,720)$. Of the total farms studied, tiestall farms with a pipeline milking system accounted for $49 \%$ (85/172). Based on the DHI data, of the 172 farms, 120 (70\%) administered aDCT to a maximum of one-quarter of their cows, and $24(14 \%)$ treated more than half their cows. Correspondingly, based on the questionnaire information, $141(82 \%)$ of these farms administered aDCT to a maximum of one-quarter of their cows, and 9 (5\%) of these farms treated more than half their cows. Thus, the proportion of aDCTtreated cows in the DHI data was higher than based on the questionnaire. The duration of the farm's selective DCT practice was from 1 to 5 years in 33 (19\%) of the farms and over 5 years in 139 (81\%).

Based on the DHI treatment records, the overall proportion of aDCT-treated cows was $25 \%(1,176 / 4,720$; Table 3). The aDCT-treated cows had a higher latelactation SCC, more mastitis treatment records during the preceding lactation, and a slightly higher 305-d milk yield than did aDCT-untreated cows. Most cows had a last test-day SCC before dry-off less than $200 \times 1,000$ cells/mL, corresponding to an $\operatorname{lnSCC}$ value of less than 5.3 (Table 3, Figure 1). However, the data also included a considerable number of aDCT-untreated cows with a composite $\mathrm{SCC} \geq 200,000$ during late lactation (Figure $1)$. The mean $( \pm \mathrm{SD})$ test day for the last $\mathrm{SCC}$ was 28 d $( \pm 17 \mathrm{~d})$ before dry-off. The proportion of mastitis treatments during 154 DIM after calving did not differ between aDCT-treated and untreated cows (Table 3). The difference in 305-d milk yield between the treat- 
ment groups was not great, and no difference existed in late-lactation test-day milk yield (Table 3, Figure 2). The breeds' proportions were Finnish Ayrshire $52 \%(2,455 / 4,720)$ and Holstein $48 \%(2,265 / 4,720)$. For untreated cows, Finnish Ayrshire accounted for $53 \%(1,892 / 3,544)$ and Holstein $47 \%(1,652 / 3,544)$. For aDCT-treated cows, Holstein accounted for $52 \%$ $(613 / 1,176)$ and Finnish Ayrshire for 48\% (563/1,176). Calvings were distributed evenly over all seasons. The mean $( \pm \mathrm{SD})$ number of test-day milk yields recorded postcalving per cow was $5.1( \pm 1.8)$ and ranged from 1 to 11 . The mean $( \pm \mathrm{SD})$ number of test-day SCC measures recorded postcalving per cow was $3.7( \pm 1.4)$, ranging from 1 to 9 . The total number of milk yield observations was 20,483, and SCC observations 14,212. The number of milk yield observations per time period ranged from 1,245 to 2,294 and SCC observations from 806 to 1,955 .

\section{Daily Milk Yield Within 154 DIM}

Figure 3 and Table 4 present the graphical and tabular displays of the model results from the time series measurement of milk yield. The marginal and conditional $\mathrm{R}^{2}$ coefficients show that the proportion of variance in milk yield explained by the fixed effects alone was $38.5 \%$, and the proportion of variance explained by the fixed and random effects together was $64.0 \%$. The estimated $\operatorname{AR}(1)$ autocorrelation coefficient $\phi$ was 0.64 .

Considering the interaction between aDCT and latelactation $\operatorname{lnSCC}$, the effect of increasing SCC on milk yield in treated versus untreated cows differed. At an
SCC of 200,000 cells/mL before dry-off, aDCT-treated cow produced $0.97 \mathrm{~kg} / \mathrm{d}$ more milk than untreated cows, whereas at an SCC of 100,000 cells/mL before dry-off, the difference was $0.75 \mathrm{~kg} / \mathrm{d}$ (Figure 3). The milk yield prediction was lower for cows treated for mastitis within 154 DIM than for those not treated, as well as for cows with higher postcalving mean lnSCC. A longer dry period and, based on a large end-lactation DIM, longer preceding lactation were associated with a higher milk yield. Furthermore, the milk yield prediction was higher for the Holstein breed than for Finnish Ayrshires, and for cows calving in winter compared with those calving in summer or autumn. Mastitis treatment during the preceding lactation and the 2-way interaction aDCT $\times$ milk yield before dry-off were omitted from the final model, when the best-fit model was selected using AIC.

\section{Composite Milk SCC Within 154 DIM}

Figure 4 and Table 5 show the graphical and tabular displays of the model results from the time series measurement of SCC. The marginal and conditional $\mathrm{R}^{2}$ coefficients show that the proportion of variance in lnSCC explained by the fixed effects was $11.7 \%$, and the proportion of variance explained by the fixed and random effects together was $55.5 \%$. Thus, the random effects compared with the fixed effects explained a considerable portion of the variability in $\operatorname{lnSCC}$. The estimated $\operatorname{AR}(1)$ autocorrelation coefficient $\phi$ was 0.53 .

The predicted $\operatorname{lnSCC}$ was lower for aDCT-treated cows than for untreated cows, and a higher SCC before dry-off was associated with higher lnSCC after calving.

Table 2. Dairy Herd Improvement information registered in 2016 on 172 conventional dairy farms that used selective antibiotic dry cow therapy (aDCT), compared with national average

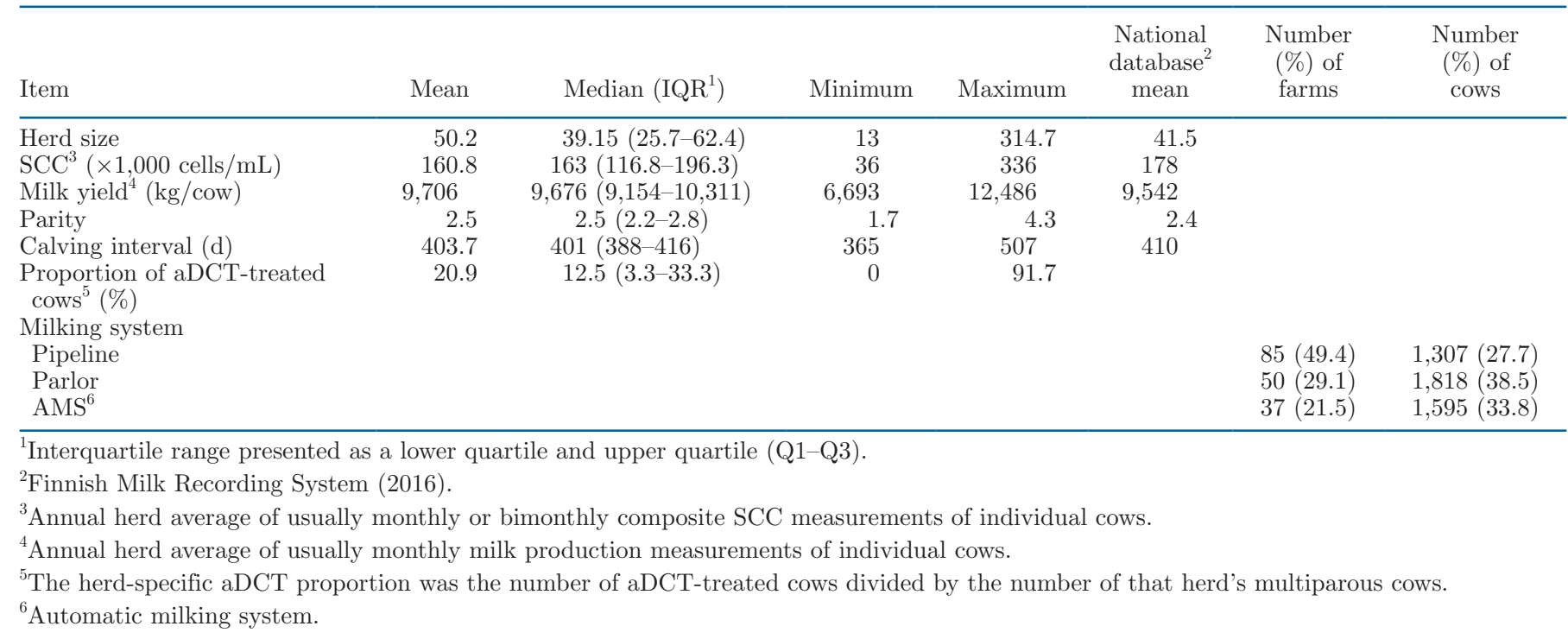




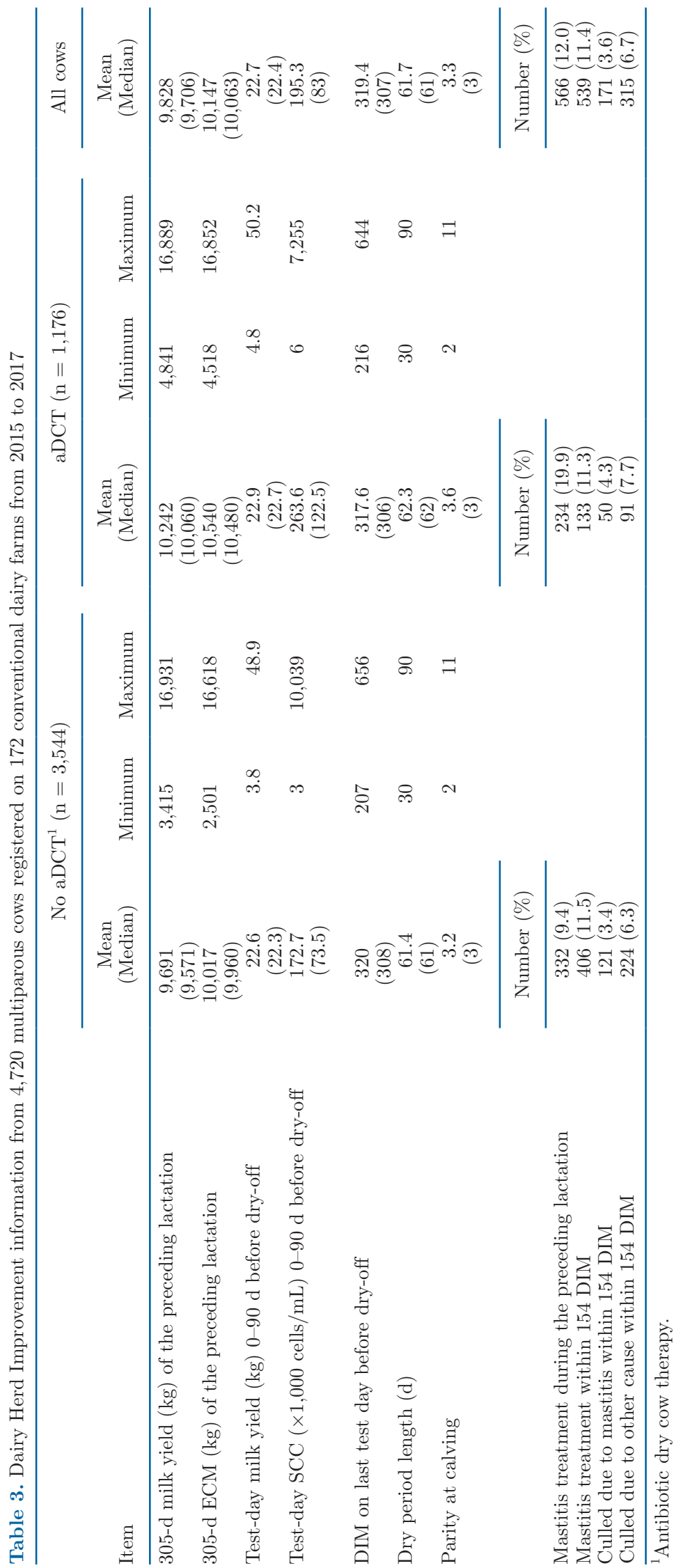




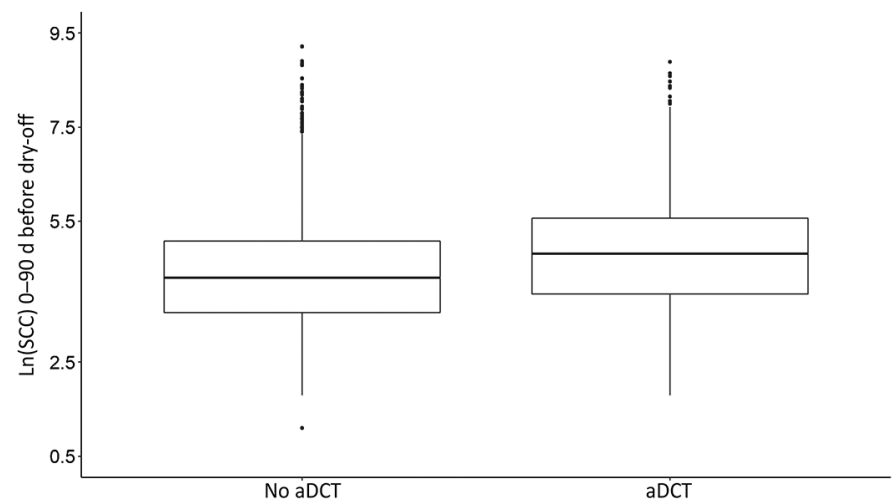

Figure 1. Conditional Tukey boxplot of last test-day naturally log-transformed $(\mathrm{ln})$ composite SCC for cows untreated $(\mathrm{n}=3,544)$ or treated $(\mathrm{n}=1,176)$ with antibiotic dry cow therapy (aDCT). The mean $( \pm \mathrm{SD})$ test day for the last SCC measurement was $28 \mathrm{~d}( \pm 17$ d) before dry-off. The upper and lower edges of boxes represent the upper and lower quartiles of the interquartile range, and the midline is the median. The whiskers show the upper and lower values within 1.5 times the interquartile range from the upper and lower quartiles. The dots represent outliers.

At an SCC of 200,000 cells/mL before dry-off, aDCTtreated cows had an SCC approximately 20,000 cells/ $\mathrm{mL}$ lower at 45 DIM compared with untreated cows, whereas at an SCC of 100,000 cells/mL before dry-off, the difference was approximately 16,000 cells/mL at 45 DIM (Figure 4). Cows treated for mastitis during preceding lactation or after calving had a higher lnSCC prediction than did cows untreated for mastitis. Higher 305-d and late-lactation milk yield in preceding lactation increased the lnSCC prediction. The Holstein breed compared with the Finnish Ayrshire breed, and

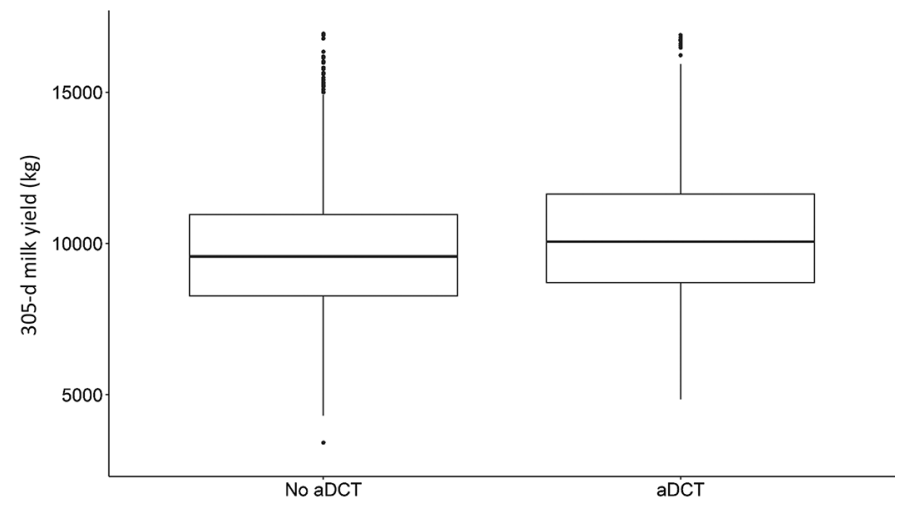

Figure 2. Conditional Tukey boxplot of the preceding-lactation 305 -d milk yield for cows untreated $(\mathrm{n}=3,544)$ or treated $(\mathrm{n}=1,176)$ with antibiotic dry cow therapy (aDCT). The upper and lower edges of boxes represent the upper and lower quartiles of the interquartile range, and the midline is the median. The whiskers show the upper and lower values within 1.5 times the interquartile range from the upper and lower quartiles. The dots represent outliers. calving in winter compared with calving in autumn, were both associated with higher $\operatorname{lnSCC}$. Dry period length, DIM on the last test day before dry-off, and the 2 -way interactions aDCT $\times \operatorname{lnSCC}$ before dry-off and aDCT $\times$ milk yield before dry-off were omitted from the final model, when the best-fit model was selected using AIC.

\section{DISCUSSION}

Although several experimental studies examine the effects of aDCT (Rajala-Schultz et al., 2011; Scherpenzeel et al., 2014; Cameron et al., 2015; Kabera et al., 2020; Rowe et al., 2020a,b), not many observational studies have drawn inferences from commercial dairy farms that use selective DCT as their standard practice (Vanhoudt et al., 2018; Niemi et al., 2020, 2021). To the best of our knowledge, the current study may be the first observational study to determine differences in SCC and milk yield during the first half of lactation between aDCT-treated and untreated dairy cows on selective-DCT farms.

In terms of milk yield, the effect of aDCT seemed to differ depending on late-lactation SCC, so that a higher test-day SCC near dry-off led to an increased difference in daily yield between treated and untreated cows. This result indicates that missing an aDCT treatment for a high-SCC cow at dry-off has a minor undesirable yield effect during the subsequent lactation. A greater increase in test-day SCC is associated with greater loss of milk production, and thus a loss of income, due to subclinical mastitis (Seegers et al., 2003; Halasa et al., 2009). The persistence of subclinical mastitis over a dry period can lead to a negative economic impact during the subsequent lactation and thus emphasizes the importance of successful selection criteria for cows in need of aDCT.

Based on experimental studies, the selective DCT approach does not adversely affect the milk yield of the following lactation (Rajala-Schultz et al., 2011; Cameron et al., 2015; Rowe et al., 2020b). Rajala-Schultz et al. (2011) showed that, during the subsequent lactation, milk yield of aDCT-treated and untreated lowSCC cows did not differ. The low-SCC categorization of that experiment was based on clinical mastitis history and SCC $\leq 200,000$ cells $/ \mathrm{mL}$ during the last 3 mo of lactation. Compared with a blanket DCT approach, the selective treatment of low-SCC cows did not seem to affect milk yield during the subsequent lactation, when all cows in the experiment received ITS at dry-off (Cameron et al., 2015; Rowe et al., 2020b).

According to the present results, aDCT reduced SCC when compared with SCC in untreated cows. By con- 


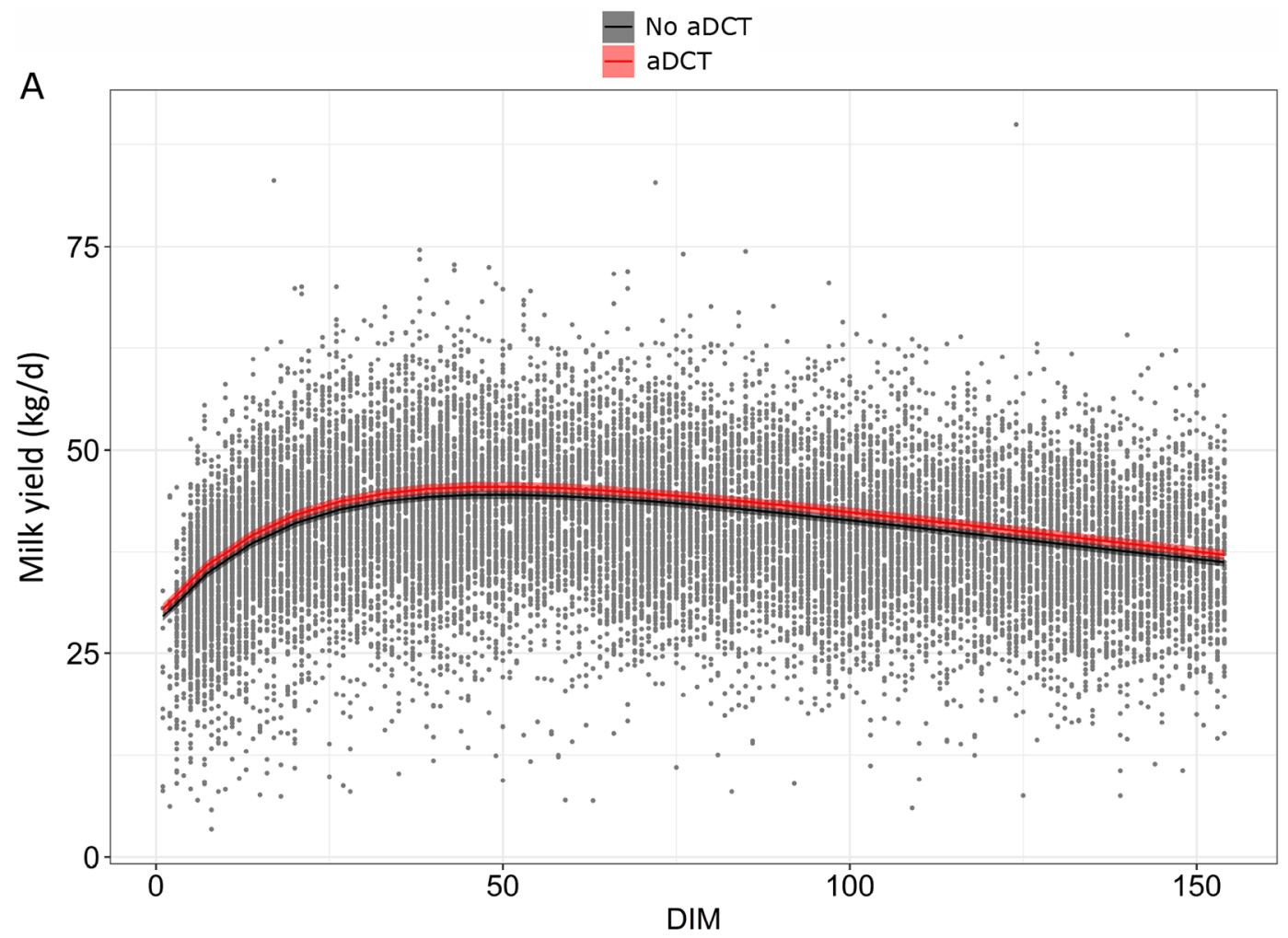

$\mathrm{B}$

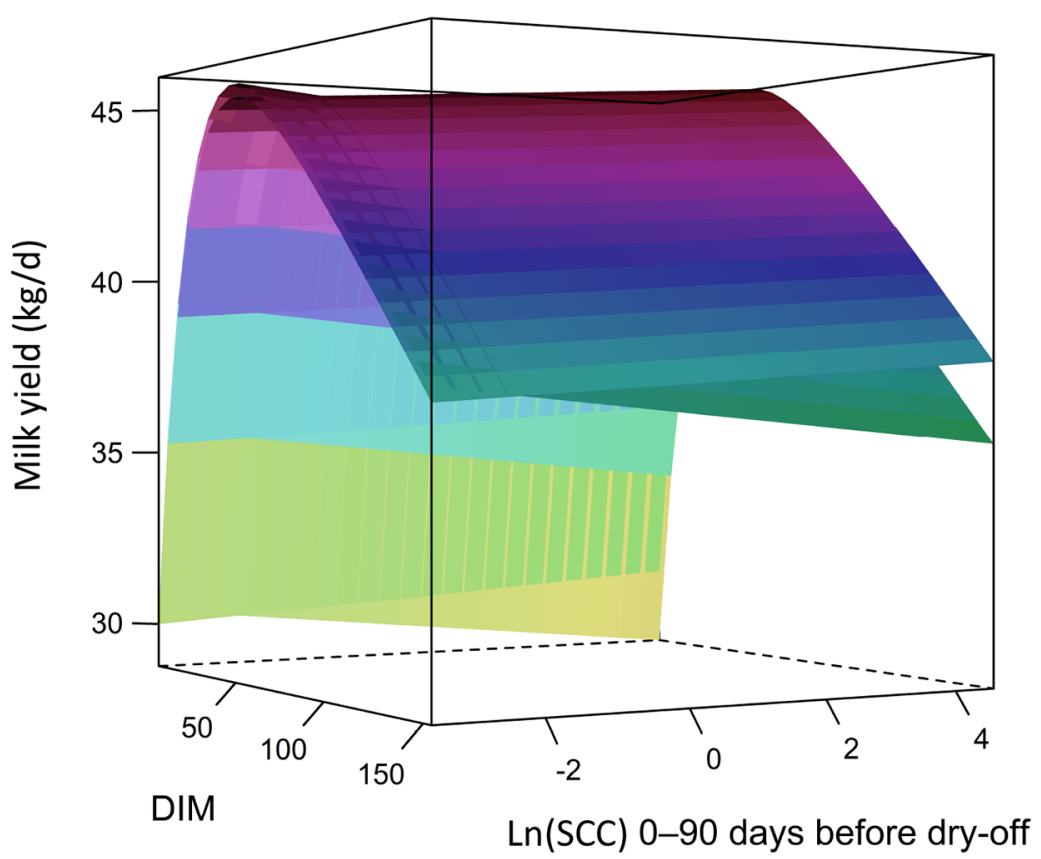

Figure 3. Fitted linear mixed model for milk yield within 154 DIM, based on 4,720 cows from 172 dairy herds (Table 4). (A) Predicted lactation curve $\pm 95 \%$ CI for a Holstein cow treated and untreated with antibiotic dry cow therapy (aDCT). The cow had no postpartum mastitis treatments, the dry period equals $60 \mathrm{~d}$, and calving season is winter. The SCC 0-90 d before dry-off is set equal to a naturally log-transformed (ln) SCC of $200 \times 1,000$ cells $/ \mathrm{mL}$. Other covariates in the model are set to be equal to the mean (305-d milk yield, DIM on the last test day before dry-off, mean SCC postpartum, and milk yield 0-90 d before dry-off). (B) Three-dimensional visualization for the model interaction between aDCT (categorical) and InSCC 0-90 d before dry-off (continuous). The upper plane represents the lactation curve for an aDCT-treated cow and the lower plane represents that for an aDCT-untreated cow. The lnSCC 0-90 d before dry-off is centered on a naturally log-transformed SCC of $100 \times 1,000$ cells $/ \mathrm{mL}$. 
Table 4. Model estimates from a linear mixed model for milk yield $(\mathrm{kg} / \mathrm{d})$ as a repeated measure within 154 DIM, based on 4,720 cows from 172 dairy herds ${ }^{1}$

\begin{tabular}{|c|c|c|c|c|c|c|}
\hline$\frac{\text { Fixed effects }}{\text { Intercept }}$ & $\begin{array}{c}\text { Coefficient } \\
46.59\end{array}$ & \multicolumn{2}{|c|}{$95 \% \mathrm{CI}$} & $\begin{array}{c}\mathrm{SE} \\
0.81\end{array}$ & $\begin{array}{r}t \text {-value } \\
57.71\end{array}$ & $\frac{P \text {-value }}{<0.0001}$ \\
\hline Lactation curve $^{2}$ & & & & & & \\
\hline DIM & -0.10 & -0.10 & -0.095 & 0.001 & -71.58 & $<0.0001$ \\
\hline Mean $\operatorname{lnSCC}$ within 154 DIM & -0.73 & -0.85 & -0.61 & 0.06 & -12.15 & $<0.0001$ \\
\hline \multicolumn{7}{|l|}{ Antibiotic dry cow therapy (aDCT) } \\
\hline No & Referent & & & & & \\
\hline \multicolumn{7}{|l|}{ aDCT $\times$ Test-day $\operatorname{lnSCC} 0-90 \mathrm{~d}$ before dry-off } \\
\hline No & Referent & & & & & \\
\hline Yes & 0.32 & 0.03 & 0.62 & 0.15 & 2.13 & 0.033 \\
\hline Test-day milk yield $(\mathrm{kg} / \mathrm{d}) 0-90 \mathrm{~d}$ before dry-off ${ }^{4}$ & 0.10 & 0.07 & 0.13 & 0.02 & 6.47 & $<0.0001$ \\
\hline $305-\mathrm{d}$ milk yield $(\times 1,000 \mathrm{~kg})$ of the preceding lactation ${ }^{5}$ & 1.61 & 1.51 & 1.71 & 0.05 & 32.15 & $<0.0001$ \\
\hline \multicolumn{7}{|l|}{ Breed } \\
\hline Finnish Ayrshire & Referent & & & & & \\
\hline \multicolumn{7}{|l|}{ Mastitis treatment within 154 DIM } \\
\hline DIM on last test day before dry-off $(\times 30 \mathrm{~d})$ & 0.17 & 0.08 & 0.26 & 0.05 & 3.64 & 0.0003 \\
\hline \multicolumn{7}{|l|}{ Season at calving } \\
\hline Winter & Referent & & & & & \\
\hline Spring & -0.43 & -0.86 & 0.004 & 0.22 & -1.94 & 0.052 \\
\hline Summer & -1.60 & -2.02 & -1.19 & 0.21 & -7.58 & $<0.0001$ \\
\hline Autumn & -0.90 & -1.32 & -0.48 & 0.22 & -4.16 & $<0.0001$ \\
\hline Random effects & Variance & \multicolumn{2}{|c|}{$\mathrm{SD}$} & & & \\
\hline Herd & 3.80 & \multicolumn{2}{|c|}{1.95} & & & \\
\hline Cow & 14.34 & \multicolumn{2}{|c|}{3.79} & & & \\
\hline Residual & 25.56 & \multicolumn{2}{|c|}{5.06} & & & \\
\hline
\end{tabular}

${ }^{1}$ Total number of observations was 20,483. The model comprised 2-level random intercepts, cows nested within herds, and a first-order autoregressive $[\mathrm{AR}(1)]$ correlation structure.

${ }^{2}$ Lactation curve modeled as presented by Wilmink (1987). The constant k was set at 0.05 .

${ }^{3}$ Centered on a naturally log-transformed SCC of $100 \times 1,000$ cells $/ \mathrm{mL}$.

${ }^{4}$ Centered on the median milk yield of $22.4 \mathrm{~kg}$.

${ }^{5}$ Centered on the median 305-d milk yield of $9.706 \times 1,000 \mathrm{~kg}$.

trast, a higher late-lactation SCC was associated in the following lactation with higher SCC. In agreement with this, Rajala-Schultz et al. (2011) showed that, although during the following lactation, aDCT-treated low-SCC cows had a lower SCC than did untreated low-SCC cows, aDCT-treated high-SCC cows had a higher SCC than did untreated low-SCC cows. Regarding only the first month after calving, the previous results likewise suggest that aDCT is associated with lower postpartum SCC (Scherpenzeel et al., 2014; Vanhoudt et al., 2018; Niemi et al., 2021). Recent experimental findings from studies administering ITS to both aDCT-treated and untreated cows suggest that leaving low-SCC cows without antibiotics at dry-off does not cause substantial harm to udder health (McParland et al., 2019; Rowe et al., 2020a,b).
Leaving uninfected cows or quarters untreated with aDCT has a major effect on antibiotic consumption (Vanhoudt et al., 2018; Kabera et al., 2020; Rowe et al., 2020a), and given the global health challenge posed by antibiotic resistance, preventive use of antibiotics no longer seems justified (WHO 2015; McEwen and Collignon, 2018). Although a cow with mastitis, based on either a high SCC or bacteriological analysis, obviously needs and benefits from aDCT, some high-SCC cows are recurrently infected or chronically infected. Our current results show that mastitis treatment during the preceding lactation was associated with higher SCC during the subsequent lactation. Pantoja et al. (2009) reported that the odds of clinical mastitis were significantly higher in quarters with clinical mastitis during the preceding lactation than in quarters with- 


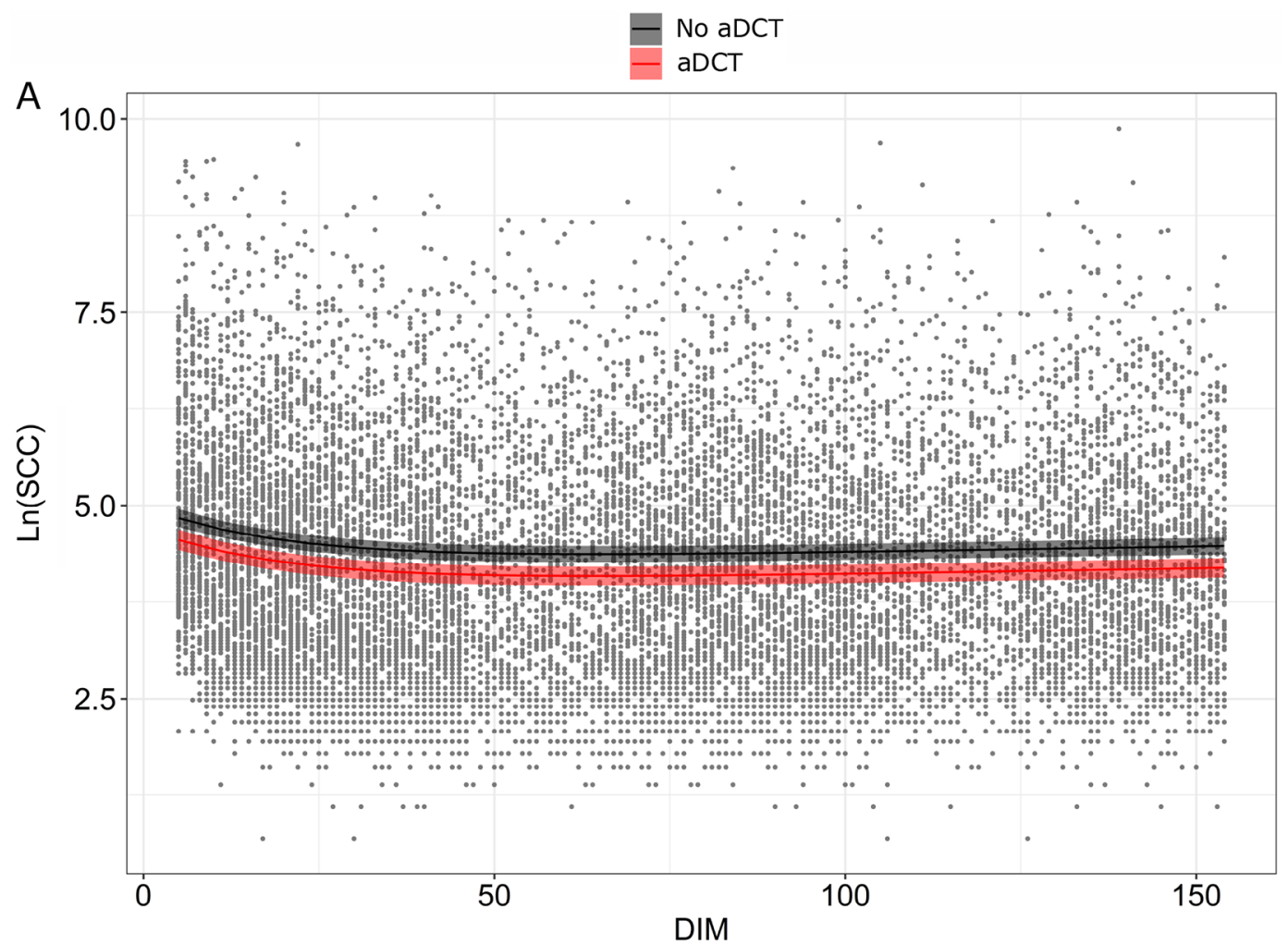

B

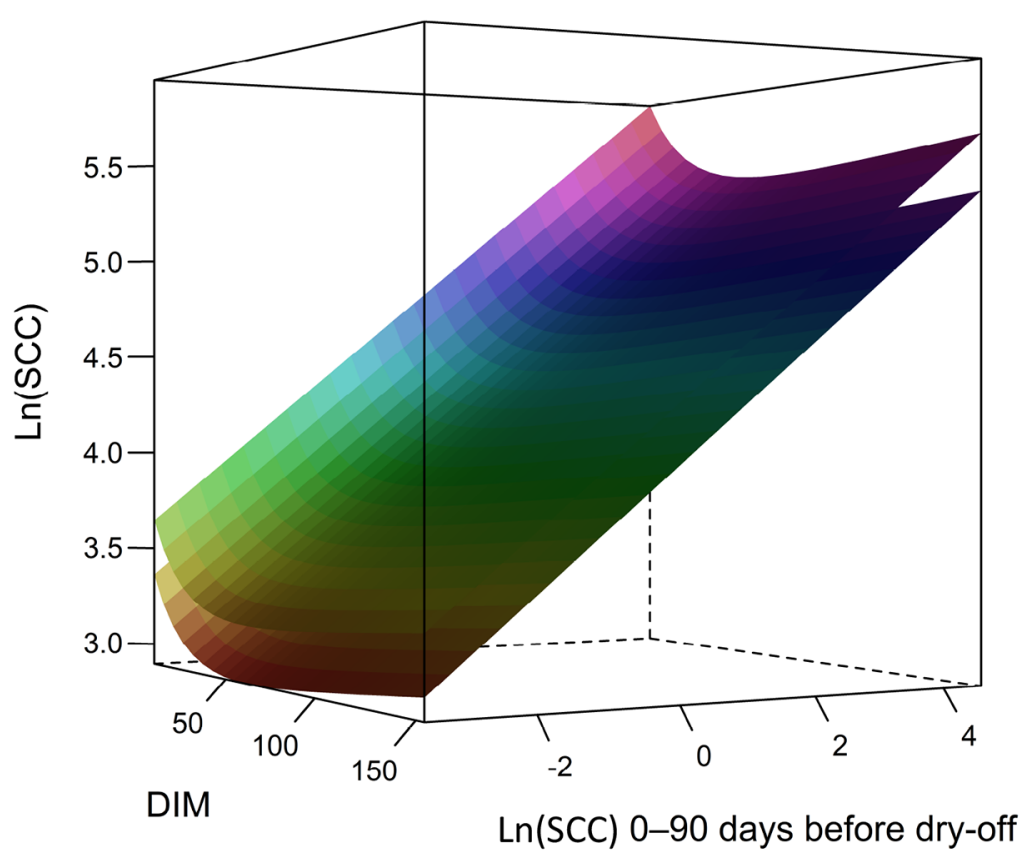

Figure 4. Fitted linear mixed model for naturally log-transformed $(\ln )$ composite SCC $(\times 1,000$ cells $/ \mathrm{mL})$ within 154 DIM, based on 4,720 cows from 172 dairy herds (Table 5). (A) Predicted $\operatorname{lnSCC} \pm 95 \%$ CI for a Holstein cow treated and untreated with antibiotic dry cow therapy (aDCT). The cow had no pre- or postpartum mastitis treatments, and calving season is winter. The SCC 0-90 d before dry-off is set equal to a naturally log-transformed SCC of $200 \times 1,000$ cells $/ \mathrm{mL}$. Other covariates in the model are set to be equal to the mean (305-d milk yield, testday milk yield after calving, and milk yield 0-90 d before dry-off). (B) Three-dimensional visualization for the model with lnSCC 0-90 d before dry-off as a continuous covariate. The upper plane represents the predicted lnSCC for an aDCT-untreated cow and the lower plane represents that for an aDCT-treated cow. The lnSCC 0-90 d before dry-off is centered on a naturally log-transformed SCC of 100 $\times 1,000$ cells $/ \mathrm{mL}$. 
Table 5. Model estimates from a linear mixed model for naturally log-transformed $(\mathrm{ln})$ composite SCC $(\times 1,000$ cells $/ \mathrm{mL})$ as a repeated measure within 154 DIM, based on 4,720 cows from 172 dairy herds ${ }^{1}$

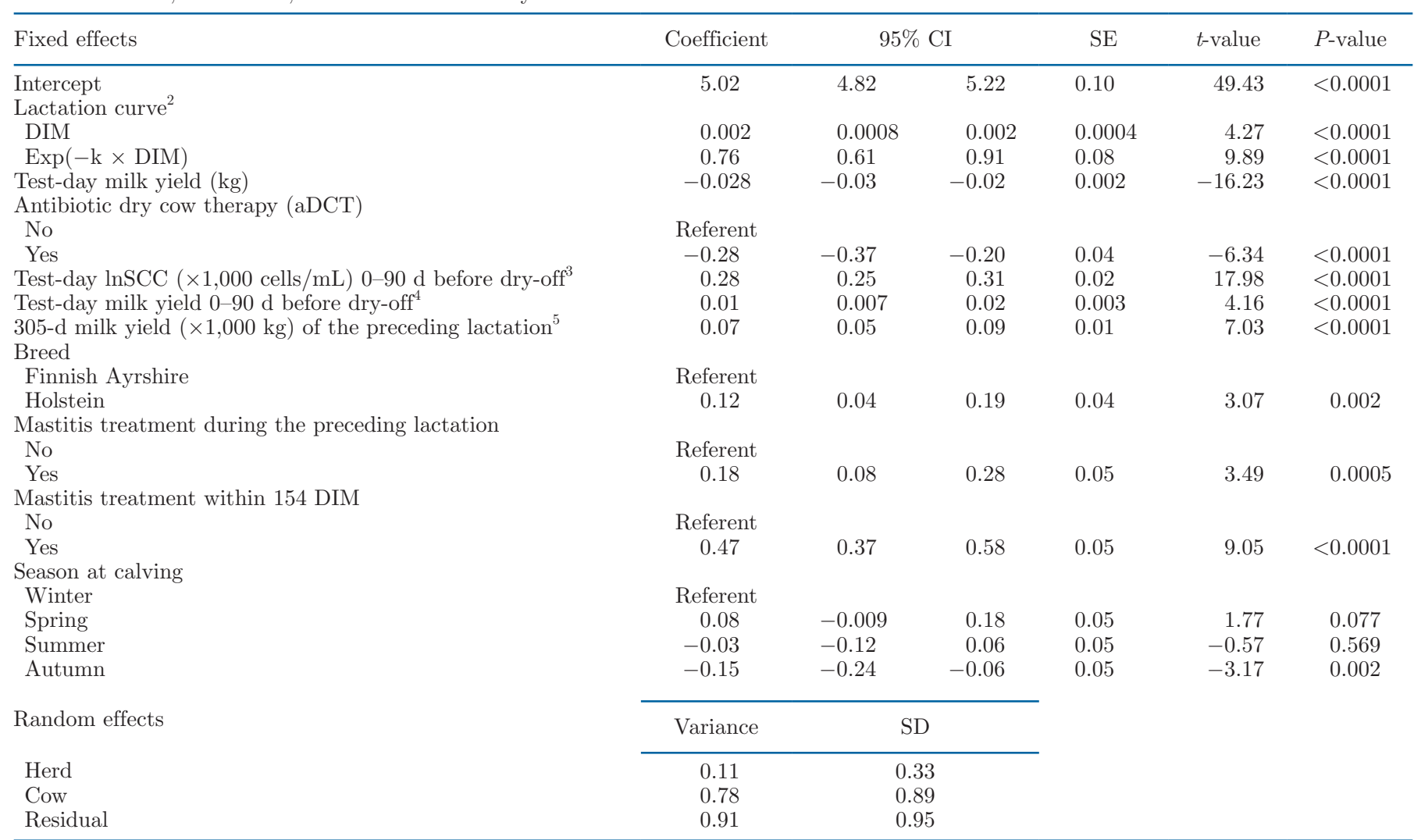

${ }^{1}$ The total number of observations was 14,212. The model comprised 2-level random intercepts, cows nested within herds, and a first-order autoregressive $[\mathrm{AR}(1)]$ correlation structure

${ }^{2}$ Lactation curve modeled as presented by Wilmink (1987). The constant k was set at 0.05 .

${ }^{3}$ Centered on a naturally log-transformed SCC of $100 \times 1,000$ cells $/ \mathrm{mL}$.

${ }^{4}$ Centered on the median milk yield of $22.4 \mathrm{~kg}$.

${ }^{5}$ Centered on the median 305-d milk yield of $9.706 \times 1,000 \mathrm{~kg}$.

out. Furthermore, aDCT-treated quarters with IMI at dry-off had higher odds of having IMI after a dry period than did aDCT-treated uninfected quarters, although the reported overall cure rate was $84 \%$ (Newman et al., 2010). High SCC during the preceding lactation appears to be a risk factor for both clinical mastitis and high SCC after the dry period (Green et al., 2007; Lipkens et al., 2019; Niemi et al., 2021). For cows with a prolonged high SCC or frequently recurrent clinical mastitis, antibiotics are likely to bring only transient improvement. Such cows can cause an increase in infectious pressure of mastitis within the herd, and recurrent treatments during lactation are uneconomical due to poor treatment response (Gussmann et al., 2019a,b).

Selective DCT is a well-established treatment recommendation in the Nordic countries (Rajala-Schultz et al., 2021). The vast majority of the selective-DCT farms of the current study appeared to treat only a judicious proportion of their cows, as the average herd-level pro- portion of aDCT-treated multiparous cows was $21 \%$. This is the first study from Finland to present aDCT treatment proportions based on DHI records, and our results align with those previously reported (Ekman and Østerås, 2003; Vilar et al., 2018). In addition to the Nordic countries, selective DCT has recently become a national approach in the Netherlands, guided by Dutch national legislation. The reported SCC thresholds of the Dutch guidelines on the use of aDCT are slightly lower than the current Finnish recommendations, and the proportions of treated cows appear to be higher (Scherpenzeel et al., 2016; Vanhoudt et al., 2018; Krattley-Roodenburg et al., 2021). The results of a recent experimental field trial showed that when cow selection was based on microbiological culture, the proportion of selectively aDCT-treated quarters ranged in herds from $32 \%$ to $62 \%$, and when selection was based on SCC and mastitis history, the proportion ranged from $19 \%$ to $68 \%$ (Rowe et al., 2020a). 
According to economic analyses, the better the udder health of the herd, the greater the economic benefit of the selective DCT approach (Scherpenzeel et al., 2018; Rowe et al., 2021). The current study showed that in Finland, the major proportion of cows have an SCC $<200,000$ cells/mL before dry-off, and overall aDCT use is low. Despite this low use of antibiotics, the quality of milk and udder health is good based on DHI recordings, geometric means of bulk tank SCC, and clinical mastitis incidence (Niemi et al., 2020; Rajala-Schultz et al., 2021). The prevailing prudent use of antibiotics at dry-off appears therefore to be economically sound. However, because data on SCC and milk production shows significant variation between herds, advice on optimal selective-DCT practices should be herd-specific (Rajala-Schultz et al., 2011; Scherpenzeel et al., 2018; Niemi et al., 2020).

The Finnish practice is to treat all quarters in cows with suspected or confirmed IMI. The preferred methods for selecting cows in need of aDCT are bacteriological analysis of the milk, examination of mastitis history, and high SCC based on DHI measurements, AMS data, or cow-side California Mastitis Test (Vilar et al., 2018). Several pathogen-specific recommendations, as well as Finnish legislation, encourage farmers to carry out comprehensive bacteriological analysis of milk samples, and the farmers also take frequent milk samples at dry-off (Vilar et al., 2018; Niemi et al., 2020; Rajala-Schultz et al., 2021). The legislation requires that regular microbiological diagnosis and susceptibility testing of samples must take place when antibiotics are used for prevalent diseases such as mastitis (Finnish Ministry of Agriculture and Forestry Regulation, 2014). In addition, medicines are available to the farmer only through a veterinarian, and veterinarians are not entitled to profit from the sale of medicines. According to the Vilar et al. (2018) survey, 35\% of Finnish herds were using ITS at dry-off in 2017, and this use was more common on larger farms with a parlor or AMS milking system. Practically all Finnish farms use a gradual milk cessation method, and the daily milk yield at dry-off is typically less than $15 \mathrm{~kg}$ (Vilar et al., 2018), which also seems to be the management practice in Dutch farms with a selective DCT approach (Krattley-Roodenburg et al., 2021). Gradual milk cessation accelerates the involution process and improves immunological defenses in the udder (Bushe and Oliver, 1987; Vilar and Rajala-Schultz, 2020), and may thus be a practice that positively supports the selective DCT approach.

The composite SCC threshold typically used for aDCT administration in Finland is SCC $\geq 200,000$ cells $/ \mathrm{mL}$ during late lactation or repeatedly during lactation, and this threshold is also standard in experi- mental field trials (Rajala-Schultz et al., 2011; Vasquez et al., 2018; McParland et al., 2019). Interestingly, the overall proportion of aDCT-treated cows in the present study was approximately the same as the recently reported proportion of Finnish cows with SCC $\geq 200,000$ cells/mL in the last SCC measurement before dry-off (Niemi et al., 2021). Mastitis history is one criterion for selection of cows for aDCT (Vilar et al., 2018), making it no surprise that our result show that the percentage of preceding-lactation mastitis treatments was more than twice as high in aDCT-treated cows as in aDCT-untreated cows. Within 154 DIM after calving, no difference in the proportion of mastitis treatments appeared between aDCT-treated and untreated cows. This suggests that selection of cows for treatment was sufficient, if assessment is based solely on treatment records.

Results from field trials that concern the effect of selective DCT on the incidence of postpartum clinical mastitis are contradictory. Scherpenzeel et al. (2014) reported an increase in the incidence rate of clinical mastitis in aDCT-untreated quarters compared with aDCT-treated quarters during 100 DIM. Cameron et al. (2014), however, found that when ITS was infused to all cows at dry-off, the overall risk for clinical mastitis was low, and the risk was the same between their selective DCT treatment group and their blanket DCT group up to 120 DIM. Economic modeling has indicated that even if a selective DCT approach were to result in a moderate increase in risk for subclinical and clinical mastitis, it could still prove more cost-effective than a blanket DCT approach (Scherpenzeel et al., 2018; Rowe et al., 2021).

The standard dry period is 6 to $8 \mathrm{wk}$, and shortening or entirely omitting the dry period is likely to reduce milk production, probably due to the period required for udder gland regeneration (Capuco and Akers, 1999; van Knegsel et al., 2013). Our results show that when we limited the maximum dry period to $90 \mathrm{~d}$, extending the dry period to more than $30 \mathrm{~d}$ led to increased milk yield. Correspondingly, Church et al. (2008) showed that a shorter, 30-d dry period reduced milk production, compared with production after a 60-d dry period. Based on meta-analysis, shortening the dry period does not seem to elevate the odds for mastitis (van Knegsel et al., 2013), and in line with this, our results show that dry period length was not associated with postcalving SCC.

\section{CONCLUSIONS}

Selective DCT is a well-established treatment recommendation in the Nordic countries, and in those com- 
mercial Finnish farms using selective DCT as standard practice, the overall proportion of aDCT-treated cows was relatively low. Due to the interaction effect, SCC on the last test day prior to dry-off affected postcalving milk yield differently in aDCT-treated cows than in untreated cows. A higher SCC prior to dry-off correlated with a greater daily yield difference after calving between cows treated and untreated. The majority of cows had a test-day SCC $<200,000$ cells/mL before dry-off, and as the SCC before dry-off decreased, the difference in yield between aDCT-treated and untreated cows decreased. Postcalving SCC was lower for aDCT-treated cows compared with untreated cows. For instance, for cows with an SCC of 200,000 cells $/ \mathrm{mL}$ before dry-off, aDCT-treated cows produced $0.97 \mathrm{~kg} / \mathrm{d}$ more milk and, at 45 DIM, had an SCC that was 20,000 cells $/ \mathrm{mL}$ lower. Higher late-lactation SCC and lactational mastitis treatments were associated with higher postcalving SCC. A dry period lasting more than $30 \mathrm{~d}$ was associated with higher yields but not with SCC. Our findings indicate that a missed aDCT treatment for a high-SCC cow has an undesirable effect on subsequent lactation milk yield and SCC, which emphasizes the importance of careful effort in the selection of cows to be treated.

\section{ACKNOWLEDGMENTS}

The authors are grateful to the farmers for their participation. Financial support came from the Finnish Veterinary Foundation (Helsinki, Finland) and from the Finnish Ministry of Agriculture and Forestry (Helsinki, Finland, grant number 568/03.01.02/2017). The authors have not stated any conflicts of interest.

\section{REFERENCES}

Anonymous. 1966. Infectious drug resistance. N. Engl. J. Med. 275:277. https://doi.org/10.1056/NEJM196608042750513.

Barkema, H. W., H. A. Deluyker, Y. H. Schukken, and T. J. G. M. Lam. 1999. Quarter-milk somatic cell count at calving and at the first six milkings after calving. Prev. Vet. Med. 38:1-9. https://doi .org/10.1016/S0167-5877(98)00142-1.

Barton, K. 2020. MuMIn: Multi-Model Inference. R package version 1.43.17. Accessed Nov. 25, 2021. https://CRAN.R-project.org/ package $=$ MuMIn .

Bertulat, S., C. Fischer-Tenhagen, and W. Heuwieser. 2015. A survey of drying-off practices on commercial dairy farms in northern Germany and a comparison to science-based recommendations. Vet. Rec. Open 2:e000068. https://doi.org/10.1136/vetreco-2014 -000068 .

Bradley, A. J., and M. J. Green. 2004. The importance of the nonlactating period in the epidemiology of intramammary infection and strategies for prevention. Vet. Clin. North Am. Food Anim. Pract. 20:547-568. https://doi.org/10.1016/j.cvfa.2004.06.010.

Bushe, T., and S. P. Oliver. 1987. Natural protective factors in bovine mammary secretions following different methods of milk cessation. J. Dairy Sci. 70:696-704. https://doi.org/10.3168/jds.S0022 -0302(87)80060-7.
Cameron, M., G. P. Keefe, J. P. Roy, H. Stryhn, I. R. Dohoo, and S. L. McKenna. 2015. Evaluation of selective dry cow treatment following on-farm culture: Milk yield and somatic cell count in the subsequent lactation. J. Dairy Sci. 98:2427-2436. https://doi.org/ $10.3168 /$ jds.2014-8876.

Cameron, M., S. L. McKenna, K. A. MacDonald, I. R. Dohoo, J. P. Roy, and G. P. Keefe. 2014. Evaluation of selective dry cow treatment following on-farm culture: Risk of postcalving intramammary infection and clinical mastitis in the subsequent lactation. J. Dairy Sci. 97:270-284. https://doi.org/10.3168/jds.2013-7060.

Capuco, A. V., and R. M. Akers. 1999. Mammary involution in dairy animals. J. Mammary Gland Biol. Neoplasia 4:137-144. https:// doi.org/10.1023/A:1018769022990.

Church, G. T., L. K. Fox, C. T. Gaskins, D. D. Hancock, and J. M. Gay. 2008. The effect of a shortened dry period on intramammary infections during the subsequent lactation. J. Dairy Sci. 91:42194225. https://doi.org/10.3168/jds.2008-1377.

Dingwell, R. T., D. F. Kelton, and K. E. Leslie. 2003. Management of the dry cow in control of peripartum disease and mastitis. Vet. Clin. North Am. Food Anim. Pract. 19:235-265. https://doi.org/ 10.1016/S0749-0720(02)00072-5.

Dingwell, R. T., K. E. Leslie, Y. H. Schukken, J. M. Sargeant, L. L. Timms, T. F. Duffield, G. P. Keefe, D. F. Kelton, K. D. Lissemore, and J. Conklin. 2004. Association of cow and quarter-level factors at drying-off with new intramammary infections during the dry period. Prev. Vet. Med. 63:75-89. https://doi.org/10.1016/j prevetmed.2004.01.012.

Dohoo, I. R., and K. E. Leslie. 1991. Evaluation of changes in somatic cell counts as indicators of new intramammary infections. Prev. Vet. Med. 10:225-237. https://doi.org/10.1016/0167 $-5877(91) 90006-\mathrm{N}$.

Ekman, T., and O. Østerås. 2003. Mastitis control and dry cow therapy in the Nordic countries. Pages 18-30 in 42nd Annual Meeting of National Mastitis Council, Fort Worth, TX. National Mastitis Council.

EMA Committee for Medicinal Products for Veterinary Use (CVMP) and EFSA Panel on Biological Hazards (BIOHAZ). 2017. EMA and EFSA Joint Scientific Opinion on measures to reduce the need to use antimicrobial agents in animal husbandry in the European Union, and the resulting impacts on food safety (RONAFA). EFSA J. 15:e04666. https://doi.org/10.2903/j.efsa.2017.4666.

Finnish Milk Recording System. 2016. Accessed Nov. 25, 2021. https:/ /www.proagria.fi/maito2017.

Finnish Ministry of Agriculture and Forestry Regulation. 2014. The Use and Supply of Medicinal Products in Veterinary Medicine. Accessed Nov. 25, 2021. https://mmm.fi/documents/1410837/ 1817140/Laakkeiden_luovutus_.pdf/a7ff23f1-83f0-4a3e-9bf5 -51babbfc837a.

Fujiwara, M., M. J. Haskell, A. I. Macrae, and K. M. D. Rutherford. 2018. Survey of dry cow management on UK commercial dairy farms. Vet. Rec. 183:297-304. https://doi.org/10.1136/vr.104755.

Green, M. J., A. J. Bradley, G. F. Medley, and W. J. Browne. 2007. Cow, farm, and management factors during the dry period that determine the rate of clinical mastitis after calving. J. Dairy Sci. 90:3764-3776. https://doi.org/10.3168/jds.2007-0107.

Gussmann, M., W. Steeneveld, C. Kirkeby, H. Hogeveen, M. Farre, and T. Halasa. 2019a. Economic and epidemiological impact of different intervention strategies for subclinical and clinical mastitis Prev. Vet. Med. 166:78-85. https://doi.org/10.1016/j.prevetmed .2019.03.001.

Gussmann, M., W. Steeneveld, C. Kirkeby, H. Hogeveen, M. Nielen, M. Farre, and T. Halasa. 2019b. Economic and epidemiological impact of different intervention strategies for clinical contagious mastitis. J. Dairy Sci. 102:1483-1493. https://doi.org/10.3168/jds 2018-14939.

Halasa, T., K. Huijps, O. Osteras, and H. Hogeveen. 2007. Economic effects of bovine mastitis and mastitis management: A review. Vet. Q. 29:18-31. https://doi.org/10.1080/01652176.2007.9695224.

Halasa, T., M. Nielen, A. P. W. De Roos, R. Van Hoorne, G. De Jong, T. J. G. M. Lam, T. Van Werven, and H. Hogeveen. 2009. Production loss due to new subclinical mastitis in Dutch dairy cows 
estimated with a test-day model. J. Dairy Sci. 92:599-606. https:/ /doi.org/10.3168/jds.2008-1564.

Kabera, F., S. Dufour, G. Keefe, M. Cameron, and J. P. Roy. 2020. Evaluation of quarter-based selective dry cow therapy using Petrifilm on-farm milk culture: A randomized controlled trial. J. Dairy Sci. 103:7276-7287. https://doi.org/10.3168/jds.2019-17438.

Krattley-Roodenburg, B., L. J. Huybens, M. Nielen, and T. van Werven. 2021. Dry period management and new high somatic cell count during the dry period in Dutch dairy herds under selective dry cow therapy. J. Dairy Sci. 104:6975-6984. https://doi.org/10 .3168/jds.2020-19133.

Larsson, D. G., C. de Pedro, and N. Paxeus. 2007. Effluent from drug manufactures contains extremely high levels of pharmaceuticals. J. Hazard. Mater. 148:751-755. https://doi.org/10.1016/j.jhazmat 2007.07.008

Lipkens, Z., S. Piepers, J. Verbeke, and S. De Vliegher. 2019. Infection dynamics across the dry period using Dairy Herd Improvement somatic cell count data and its effect on cow performance in the subsequent lactation. J. Dairy Sci. 102:640-651. https://doi.org/ $10.3168 /$ jds.2018-15130.

McEwen, S.A., and P.J. Collignon. 2018. Antimicrobial resistance: A One Health perspective. Microbiol. Spectrum 6:6.2.10. https://doi .org/10.1128/microbiolspec.ARBA-0009-2017.

McParland, S., P. G. Dillon, J. Flynn, N. Ryan, S. Arkins, and A. Kennedy. 2019. Effect of using internal teat sealant with or without antibiotic therapy at dry-off on subsequent somatic cell count and milk production. J. Dairy Sci. 102:4464-4475. https://doi.org/10 $.3168 /$ jds.2018-15195.

Nakagawa, S., and H. Schielzeth. 2013. A general and simple method for obtaining $\mathrm{R}^{2}$ from generalized linear mixed-effects models. Methods Ecol. Evol. 4:133-142. https://doi.org/10.1111/j.2041 -210x.2012.00261.x.

Neave, F. K., F. H. Dodd, R. G. Kingwill, and D. R. Westgarth. 1969. Control of mastitis in the dairy herd by hygiene and management. J. Dairy Sci. 52:696-707. https://doi.org/10.3168/jds.S0022 -0302(69)86632-4.

Newman, K. A., P. J. Rajala-Schultz, F. J. Degraves, and J. Lakritz. 2010. Association of milk yield and infection status at dry-off with intramammary infections at subsequent calving. J. Dairy Res. 77:99-106. https://doi.org/10.1017/S0022029909990380.

Niemi, R. E., M. Hovinen, M. J. Vilar, H. Simojoki, and P. J. Rajala-Schultz. 2021. Dry cow therapy and early lactation udder health problems - Associations and risk factors. Prev. Vet. Med. 188:105268. https://doi.org/10.1016/j.prevetmed.2021.105268.

Niemi, R. E., M. J. Vilar, I. R. Dohoo, M. Hovinen, H. Simojoki, and P. J. Rajala-Schultz. 2020. Antibiotic dry cow therapy, somatic cell count, and milk production: Retrospective analysis of the associations in dairy herd recording data using multilevel growth models. Prev. Vet. Med. 180:105028. https://doi.org/10.1016/j.prevetmed .2020 .105028 .

Nordic Guidelines for Mastitis Therapy. 2009. Nordic Guidelines for Mastitis Therapy. Accessed Nov. 25, 2021. https://www.sva.se/ media/qsljw2yb/nordic-guidelines-for-mastitis-therapy.pdf.

OIE. 2016. The OIE Strategy on Antimicrobial Resistance and the Prudent Use of Antimicrobials. Accessed Jun. 24, 2021. https:// www.oie.int/app/uploads/2021/03/en-oie-amrstrategy.pdf.

Pantoja, J. C., C. Hulland, and P. L. Ruegg. 2009. Somatic cell count status across the dry period as a risk factor for the development of clinical mastitis in the subsequent lactation. J. Dairy Sci. 92:139148. https://doi.org/10.3168/jds.2008-1477.

Pinheiro, J., D. Bates, S. DebRoy, D. Sarkar, and R Core Team. 2021. nlme: Linear and Nonlinear Mixed Effects Models. R package version 3.1-152. Accessed Nov. 25, 2021. https://CRAN.R-project .org $/$ package $=$ nlme

Rabiee, A. R., and I. J. Lean. 2013. The effect of internal teat sealant products (Teatseal and Orbeseal) on intramammary infection, clinical mastitis, and somatic cell counts in lactating dairy cows: A meta-analysis. J. Dairy Sci. 96:6915-6931. https://doi.org/10 $.3168 /$ jds.2013-6544.
Rajala-Schultz, P., A. Nødtvedt, T. Halasa, and K. Persson Waller. 2021. Prudent use of antibiotics in dairy cows: The Nordic approach to udder health. Front. Vet. Sci. 8:623998. https://doi.org/ 10.3389/fvets.2021.623998.

Rajala-Schultz, P. J., Y. T. Gröhn, C. E. McCulloch, and C. L. Guard. 1999. Effects of clinical mastitis on milk yield in dairy cows. J. Dairy Sci. 82:1213-1220. https://doi.org/10.3168/jds.S0022 -0302(99)75344-0.

Rajala-Schultz, P. J., A. H. Torres, and F. J. DeGraves. 2011. Milk yield and somatic cell count during the following lactation after selective treatment of cows at dry-off. J. Dairy Res. 78:489-499. https://doi.org/10.1017/S0022029911000690.

Rowe, S. M., S. M. Godden, D. V. Nydam, P. J. Gorden, A. Lago, A. K. Vasquez, E. Royster, J. Timmerman, and M. J. Thomas. 2020a. Randomized controlled non-inferiority trial investigating the effect of 2 selective dry-cow therapy protocols on antibiotic use at dry-off and dry period intramammary infection dynamics. J. Dairy Sci. 103:6473-6492. https://doi.org/10.3168/jds.2019-17728.

Rowe, S. M., S. M. Godden, D. V. Nydam, P. J. Gorden, A. Lago, A. K. Vasquez, E. Royster, J. Timmerman, and M. J. Thomas. 2020b. Randomized controlled trial investigating the effect of 2 selective dry-cow therapy protocols on udder health and performance in the subsequent lactation. J. Dairy Sci. 103:6493-6503. https://doi .org/10.3168/jds.2019-17961.

Rowe, S. M., D. V. Nydam, S. M. Godden, P. J. Gorden, A. Lago, A. K. Vasquez, E. Royster, J. Timmerman, M. J. Thomas, and R. A Lynch. 2021. Partial budget analysis of culture- and algorithmguided selective dry cow therapy. J. Dairy Sci. 104:5652-5664. https://doi.org/10.3168/jds.2020-19366.

Sarkar, D. 2008. Lattice: Multivariate Data Visualization with R. Springer. Accessed Nov. 25, 2021. https://lmdvr.r-forge.r-project .org.

Scherpenzeel, C. G. M., I. E. M. den Uijl, G. van Schaik, R. G. M. Olde Riekerink, J. M. Keurentjes, and T. J. G. M. Lam. 2014. Evaluation of the use of dry cow antibiotics in low somatic cell count cows. J. Dairy Sci. 97:3606-3614. https://doi.org/10.3168/ jds.2013-7655.

Scherpenzeel, C. G. M., H. Hogeveen, L. Maas, and T. Lam. 2018. Economic optimization of selective dry cow treatment. J. Dairy Sci. 101:1530-1539. https://doi.org/10.3168/jds.2017-13076.

Scherpenzeel, C. G. M., S. H. W. Tijs, I. E. M. den Uijl, I. M. G. A. Santman-Berends, A. G. J. Velthuis, and T. J. G. M. Lam. 2016. Farmers' attitude toward the introduction of selective dry cow therapy. J. Dairy Sci. 99:8259-8266. https://doi.org/10.3168/ jds. 2016-11349.

Seegers, H., C. Fourichon, and F. Beaudeau. 2003. Production effects related to mastitis and mastitis economics in dairy cattle herds. Vet. Res. 34:475-491. https://doi.org/10.1051/vetres:2003027.

Sordillo, L. M., K. Shafer-Weaver, and D. DeRosa. 1997. Immunobiology of the mammary gland. J. Dairy Sci. 80:1851-1865. https:// doi.org/10.3168/jds.S0022-0302(97)76121-6.

USDA. 2016. Milk Quality, Milking Procedures, and Mastitis on U.S. Dairies, 2014. Accessed Nov. 25, 2021. https://www.aphis.usda .gov/animal_health/nahms/dairy/downloads/dairy14/Dairy14 _dr_Mastitis.pdf.

van Knegsel, A. T. M., S. G. A. van der Drift, J. Čermáková, and B. Kemp. 2013. Effects of shortening the dry period of dairy cows on milk production, energy balance, health, and fertility: A systematic review. Vet. J. 198:707-713. https://doi.org/10.1016/j.tvjl .2013.10.005.

Vanhoudt, A., K. van Hees-Huijps, A. T. M. van Knegsel, O. C. Sampimon, J. C. M. Vernooij, M. Nielen, and T. van Werven. 2018. Effects of reduced intramammary antimicrobial use during the dry period on udder health in Dutch dairy herds. J. Dairy Sci. 101:3248-3260. https://doi.org/10.3168/jds.2017-13555.

Vasquez, A.K., D. V Nydam, C. Foditsch, M. Wieland, R. Lynch, S. Eicker, and P.D. Virkler. 2018. Use of a culture-independent on-farm algorithm to guide the use of selective dry-cow antibiotic therapy. J. Dairy Sci. 101:5345-5361. https://doi.org/10.3168/jds .2017-13807. 
Vilar, M. J., M. Hovinen, H. Simojoki, and P. J. Rajala-Schultz. 2018. Short communication: Drying-off practices and use of dry cow therapy in Finnish dairy herds. J. Dairy Sci. 101:7487-7493. https: //doi.org/10.3168/jds.2018-14742.

Vilar, M. J., and P. J. Rajala-Schultz. 2020. Dry-off and dairy cow udder health and welfare: Effects of different milk cessation methods. Vet. J. 262:105503. https://doi.org/10.1016/j.tvjl.2020.105503.

Wickham, H. 2016. Ggplot2-Elegant Graphics for Data Analysis. Springer-Verlag. Accessed Nov. 25, 2021. https://ggplot2.tidyverse .org/.

Wilmink, J. B. M. 1987. Adjustment of test-day milk, fat and protein yield for age, season and stage of lactation. Livest. Prod. Sci. 16:335-348. https://doi.org/10.1016/0301-6226(87)90003-0.

Winder, C. B., J. M. Sargeant, D. Hu, C. Wang, D. F. Kelton, S. J. Leblanc, T. F. Duffield, J. Glanville, H. Wood, K. J. Churchill, J. Dunn, M. D. Bergevin, K. Dawkins, S. Meadows, B. Deb, M. Reist, C. Moody, and A. M. O'Connor. 2019a. Comparative efficacy of teat sealants given prepartum for prevention of intramammary infections and clinical mastitis: A systematic review and network meta-analysis. Anim. Health Res. Rev. 20:182-198. https://doi .org/10.1017/S1466252319000276

Winder, C. B., J. M. Sargeant, D. F. Kelton, S. J. Leblanc, T. F. Duffield, J. Glanville, H. Wood, K. J. Churchill, J. Dunn, M. D.
Bergevin, K. Dawkins, S. Meadows, and A. M. O'Connor. 2019b. Comparative efficacy of blanket versus selective dry-cow therapy: A systematic review and pairwise meta-analysis. Anim. Health Res. Rev. 20:217-228. https://doi.org/10.1017/S1466252319000306.

World Health Organization. 2015. Global action plan on antimicrobial resistance. Accessed Nov. 25, 2021. https://apps.who.int/iris/ handle/10665/193736.

Zuur, A. F., and E. N. Ieno. 2016. A protocol for conducting and presenting results of regression-type analyses. Methods Ecol. Evol. 7:636-645. https://doi.org/10.1111/2041-210X.12577.

Zuur, A. F., E. N. Ieno, and C. S. Elphick. 2010. A protocol for data exploration to avoid common statistical problems. Methods Ecol. Evol. 1:3-14. https://doi.org/10.1111/j.2041-210X.2009.00001.x.

\section{ORCIDS}

R. E. Niemi $\odot$ https://orcid.org/0000-0001-7212-1504

M. Hovinen ๑ https://orcid.org/0000-0002-2105-1232

P. J. Rajala-Schultz @ https://orcid.org/0000-0003-4813-5097 